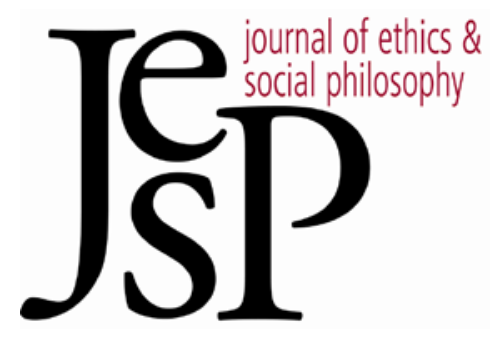

\title{
Virtuous and Vicious Anger
}

\author{
BY NiCOLAS BOMMARITO
}

JoURNAL OF ETHICS \&SOCIAL PHILOSOPHY

VoL. 11, No. 3 | MARCH 2017 URL: WWW.JESP.ORG COPYRIGHT @ NICOLAS BOMMARITO 2017 


\title{
Virtuous and Vicious Anger
}

\author{
Nicolas Bommarito
}

It's the people we love the most who can make us feel the gladdest ... and the maddest! ... It's a different kind of anger from the kind we may feel toward strangers because it is so deeply intertwined with caring and attachment.

-Fred Rogers, The World According to Mister Rogers ${ }^{1}$

$\mathrm{H}$ is incompatible with virtue. I reject both views and instead defend the idea that anger can be virtuous but is not necessary for being virtuous. On the view I will defend here, anger is made morally virtuous or vicious by the underlying concerns it manifests. Anger can, as Fred Rogers pointed out, be deeply connected with our cares - we are sometimes angry with those close to us because we care about them and it matters to us how their lives go. When connected with moral cares or concerns, some types of anger, like righteous indignation, can reflect well on our moral character.

The idea that anger can be virtuous has not been obvious to everyone. Stoic and Buddhist philosophers argue that one should never be angry.2 There is something to this. One could be forgiven for taking anger to be a categorically vicious emotion. When we think of moral exemplars like Mother Teresa or the Dalai Lama, it is tempting to picture a gentle and calm temperament that seems at odds with being angry. Seneca, for example, writes of anger:

Let us be free from this evil, let us clear our minds of it, and extirpate root and branch a passion which grows again wherever the smallest particle of it finds a resting-place. Let us not moderate anger, but get rid of it altogether: what can moderation have to do with an evil habit? 3

On the other hand, Aristotle and those inspired by his account of virtue think of some anger as required for being virtuous; the virtuous person must be angry, albeit at the right time and place and in the right way. ${ }^{4}$ Common sense, at least in contemporary America, tends toward this view; many imagine the virtuous person as someone who does get angry, but only when it is fitting.

Many of us are caught in the middle. Hume, for example, seems to side with Aristotle, but his tone is almost apologetic, describing anger as an "indulgence" to human nature:

\footnotetext{
1 Rogers (2003).

2 See McRae (2015) and Vernezze (2008) for comparisons of Buddhist and Stoic views on anger.

${ }^{3}$ Seneca, De Ira, III.42.

${ }^{4}$ See Nicomachean Ethics, IV.5.
} 
We are not, however, to imagine, that all the angry passions are vicious, tho' they are disagreeable. There is a certain indulgence due to human nature in this respect. Anger and hatred are passions inherent in our very frame and constitution. The want of them, on some occasions, may even be a proof of weakness and imbecility. ${ }^{5}$

Both of these positions on anger are in need of support - what, after all, is so vicious about it? And what might be so virtuous about the "right" kind?

My focus here is on how anger itself, rather than its outward expressions, can be morally virtuous or vicious. It is important to distinguish between being angry and behaving angrily. These can often come apart. One might, for example, scream and shout at a child when doing so would prevent him from burning his hand or running into speeding traffic. One can speak angrily when on the phone with customer service to get a better refund. Someone can behave in this way, acting as an angry person does, without having the inner experience of anger. One can accept that expressing anger is sometimes good while denying that actually being angry is good. ${ }^{6}$

I am concerned with anger as a response that can manifest what matters to us. Anger can certainly be good or bad in other ways, such as by tending to motivate certain actions; it can be a help or hindrance to achieving certain goals like political change. There are a few reasons for this focus. Not only are these associations highly contingent, but those who reject anger as virtuous can simply say that the ideal is to perform such actions without being angry. Perhaps more importantly, not every state that is useful for promoting good or useful actions is virtuous. Someone who finds shoplifting to be disgustingly low-class is in a state that prevents her from doing something morally wrong, but it does not reflect very well on her moral character.

Though anger is often discussed as an emotion, my discussion will apply to a wider range of cases. Emotions are, for example, often taken to be episodic responses involving bodily changes. So anger as an emotion in this sense is a short-term episode that brings with it things like a raised heart rate and sweaty palms. But if someone says, "I've been angry with my brother for years," they do not mean that they have had an elevated heart rate and sweaty palms for several years. Anger can also be a more long-term attitude and my claims apply to this type of anger as well. My account of virtuous and vicious anger does not rely on any particular account of emotion - it only requires that anger can be warranted or not and that it can sometimes manifest what we care about. 7

${ }^{5}$ Hume (1978/1738) Treatise III.3.3. See also Pettigrove (2012) who argues, with Hume, that meekness is a virtue.

${ }^{6}$ These are sometimes treated together, as in Cogley (2014) who talks of the communicative value of anger. In a Buddhist context, cases like this can be seen as skillful means (or in Sanskrit upāya). There are, of course, important moral issues related to the expression of anger especially how expressions of anger are treated differently based on a person's race or gender. I try to keep such issues in view, but treating them directly is beyond the scope of this paper. See Kim (2013) for a helpful starting point for these issues.

7 Various theories of emotion explain how they can be warranted in different ways: the Stoics (see DeBrabander (2004: 202-3) and Long (2002: 213ff.)) and more recently Robert Solomon 
Finally, I focus on how anger relates to our moral character rather than how it relates to our character more generally. I do not argue, for example, that anger makes one's life more or less flourishing, more or less meaningful, aesthetically better or worse, or more or less happy. I take evaluations of moral character to be more or less separable from these other kinds of evaluations; so I assume that, for example, one may live a happier but less moral life or vice versa. ${ }^{8}$

Though my arguments fit most easily with a conception of virtue as being essentially about having a positive relation to moral goods, this is not to say that other theories cannot accept the arguments I make about how anger relates to our moral character. ${ }^{9}$ I do not mean to rely on any particular theoretical account of moral virtue; when I use examples of moral virtue and vice, I intend for them to be clear cases of what a non-philosopher might say "makes someone a good person." So in rejecting what particular Buddhists, Stoics, and Aristotelians have claimed, I do not mean to say that these general views of virtue cannot be modified to accept my specific claims about anger.

Anger, I argue, is morally virtuous when it is a manifestation of concern for moral goods. ${ }^{10}$ This is at odds with both the Stoic and Buddhist view that anger cannot be virtuous and the Aristotelian view that some fitting anger is required for virtue. This is not primarily a claim about our dispositions to anger nor is it primarily about our reflective endorsement (or lack thereof) of our anger. It is an account of anger's place in overall moral virtue, of when and why it is morally virtuous or vicious. I will defend two major claims that follow from this account. The first is that anger can be morally virtuous; it can contribute to overall virtue. The second is that it is not required for it; failures to feel anger (even when it would be warranted) are not always moral defects.

Though it might seem obvious to think that virtue requires that we be angry at the right things and fail to be angry at the wrong things, I think this is mistaken. What matters, at least for moral character, is that one cares about the right things. When such moral concern manifests as anger, it is virtuous. But

(2007) take emotions themselves to be judgments. Others describe them as having various aspects like beliefs (Kenny (1963), Marks (1982) and Ben-Ze'ev (2000: 52ff.)), construals (Roberts (1988)) or representations (Charland (1997)). Sparser theories take emotions to be warranted when caused in the right way (Prinz (2004: 54-56)). I take emotions to involve both appraisals and to motivate action (see Scarantino (2014)). Though I take emotions to be the sort of state that can be warranted or not, I will not argue that being warranted plays a role in whether or not they are virtuous and I will not rely on any particular account of their nature. 8 See Wolf (1982) for the classic defense of this idea.

9 This family of views on moral virtue includes a number of theorists: Hurka (2001) sees virtue as about loving goods and hating evils, Adams (2006) as "being for" the good, and Arpaly and Schroeder (2016) as a special kind of intrinsic desire for moral goods. In Bommarito (forthcoming) I defend a similar conception of virtue - as states that manifest moral care or concern.

${ }^{10}$ I will not defend any particular account of what those moral goods are, but I appeal to uncontroversial examples like the wellbeing or rights of others. (If these seem mistaken to you, you should feel free to use your own favorite moral good.) My account of virtuous and vicious anger need not hang on any particular account of moral goods. 
since a variety of factors irrelevant to moral character can sever the link between our concern and our emotions, such anger is not a requirement for being virtuous. This not only avoids making purely cognitive deficits into moral vices, but also allows for emotional and cultural diversity among morally virtuous people.

I start by rejecting several arguments that attempt to show that all anger is vicious. Doing so will help to illuminate various types of anger and sharpen what is not vicious about it. Next, I defend my own account of how anger relates to our moral character. On my view, anger is virtuous when it manifests moral concerns and vicious when it manifests moral indifference or immoral concerns. ${ }^{11}$ I then argue that anger can be virtuous in this way even when it is out of proportion or not fitting for the situation. I apply the account to show how a particular type of anger, righteous indignation, can count as morally virtuous in this way. Finally, I argue that anger is not required for being a morally virtuous person by focusing on cases in which failures to get angry do not make one a morally worse person.

\section{Anger as Categorically Vicious}

Many philosophers, particularly those influenced by Buddhism and Stoicism, have argued that anger is always vicious. ${ }^{12}$ Here I respond to four common strands of argument that aim to show that anger is categorically vicious and explain why these arguments fail. This will serve not only to show what is not vicious about anger, but will help sharpen the range of responses that count as anger and narrow down those that might count as morally virtuous.

\section{a. Anger is vicious because it entails a desire for retribution or harm.}

Many have argued that being angry with someone entails a desire to lash out at them, to harm them. This aspect is common in historical sources: Aristotle's anger (Greek: orge) involves a desire for revenge, and the Buddhist notion (Sanskrit: pratigha, Tibetan: khong khro) is also often defined in a way that in-

11 By manifest I mean something more than pure causation; it is not merely that our concern causes our anger, but it is the way our concern is realized in the emotional domain. This is similar to other cases in which a more general attitude manifests in a particular act or state, for example, when a joke manifests someone's sense of humor or when racial tension in a city manifests as a riot. Just as the sense of humor is, in a way, present in the joke, one's concern is present in the anger, not just the cause of it. I discuss this use of manifestation and how it relates to morally virtuous states in more detail in Bommarito (forthcoming).

12 Of course, Buddhism includes a wide range of views and practices, some of which seem to involve anger in various ways. Some forms of Buddhism, for example, acknowledge classes of deities such as Heruka (in Tibetan, khrag 'thung, literally "blood drinker") and Dharmapäla, who compassionately take on fierce and terrifying forms to destroy ignorance and protect Buddhist teachings. See Dalton (2011) for more detailed discussion of violent themes and images in Tibetan Buddhism. More philosophically, see Donner (2002), who sees a place for anger in a Buddhist framework, and McRae (2015: 471ff.), who gives a clear defense of the value of Tantric anger. 
cludes a desire to harm the object of our anger.13 This strand can also be found in more modern definitions. This is made explicit by Aaron Ben-Ze'ev:

The urge to attack is essential to anger, even if it is expressed in a nonstandard aggressive act. In anger we want to personally punish the other person who is seen as deserving of punishment. ${ }^{14}$

On these views, anger entails a desire to harm, or at least be aggressive, to others. This is anger as, at its core, the desire for payback. This suggests a simple argument showing anger to be vicious: all anger entails a desire to harm the perceived offender. Any emotion that involves a desire to harm is morally vicious. Therefore, all anger is morally vicious. ${ }^{15}$

It is important to note that this argument need not rely on the idea that anger always produces harmful behavior. One might take the desire to harm itself to be vicious; someone who never harms others but spends all day stewing in their desire to murder is morally worse even though they do not actually harm others.

The argument partially hinges on a dispute about retributive justice: is the desire to harm another always vicious or is it (at least sometimes) acceptable? It might seem plausible to some that the desire to harm a pedophile or a mass murderer can reflect well on one's moral character. Aquinas, for example, accepted that anger involves a desire for revenge, but claims that revenge may be desired "both well and ill." 16 Though this is one way to respond to the argument, I will not make use of it here.

Instead, I deny that all anger involves a desire to harm someone. ${ }^{17}$ Consider a few everyday cases of anger: Alex gets angry with her father for constantly interrupting her while she is speaking. Tina is angry with her husband for driving too fast and not carefully enough. Seth is angry with his childhood friend Julie for staying with her abusive boyfriend. We naturally apply the term anger to these cases, but they do not involve any desire to harm, punish or exact revenge. This does not mean no desire is present; it is just not a desire for harm or revenge. Alex does not desire to hurt or punish her father, she just wants him to shut up and let her talk already. Tina does not want to harm her husband, in fact, her anger stems from a desire for his safety. Seth does not want revenge; he is angry with Julie for refusing to remove herself from harm. ${ }^{18}$

${ }^{13}$ For example, the Tibetan thinker Jamgön Kongtrül's (Tibetan: 'Jam mgon kong sprul) definition includes having a "hostile or cruel frame of mind."

14 Ben-Ze'ev (2000: 384). See also Oakley (1992: 15), who includes "the desire to retaliate against the offender," Hurka (2001: 93), and West (2016).

15 Martha Nussbaum's recent criticisms of anger are largely on these grounds; see Nussbaum (2015) and (2016).

16 Summa Theologiae, question 158.

17 I am not alone in denying this: this aspect is absent in the account of anger offered by Nico Frijda (1987: 217ff.).

18 Wolf (2011) gives similar cases in the context of blame. Her examples are of a daughter who frequently borrows clothes from your closet without asking or a husband who says, "I'm 
Or consider a more serious case: think of a woman who feels angry that nobody believes her about being sexually assaulted. She may be angry with those who refuse to believe her about what happened, but she may not want to harm them - just fervently want them to take her word about what happened. ${ }^{19}$

There is also some empirical evidence that the desire to harm or get revenge is not a necessary component of all anger. The link between anger and aggressive behavior is contingent and depends on a variety of other beliefs about things like the value of venting. ${ }^{20}$ One study of American men and women found that when subjects reported feeling angry, many (82 percent) reported an impulse to verbal aggression, while far fewer (40 percent) reported an impulse to physical aggression. Verbal aggression is, of course, still aggression, but nearly 18 percent of people reported no impulse to any kind of aggression. In fact, a desire to harm another was "less common than the desire to talk things over, either with the instigator (in 59 percent of the episodes) or with a neutral third party (in 52 percent of the episodes)." ${ }_{21}$ A stubborn theorist will, of course, insist that the subjects are simply incorrect about whether or not they are really angry, about what their own impulses are or both. These data, however, do suggest that a desire to harm others is not generally taken to be a necessary condition of all anger.

It is worth keeping in mind that one can be aggressive without a desire to harm another and one can desire to harm another without being aggressive. Some bullies harm those weaker than they are with a cold and calm demeanor. Tina might aggressively shout at John in the hopes of making him safer by getting him to driver slower.

In real life, anger can manifest in behavior in an incredibly wide range of ways. Until recently, this has been overlooked by much work on anger and aggression. After reading most academic papers on anger, the first expressions that come to mind are likely to be things like yelling at someone or hitting them. But anger expressions are by no means limited to these kinds of actions. We can express anger in myriad ways: we might cry, gossip, clean the house, bite our nails, buy things online, or run faster on a morning jog.22 It is worth noting the variety of impulses and expressions associated with anger and keeping in mind that not all of them involve harm to others.

This is not to say that anger never manifests a desire to harm others, only that it need not. Much of the anger we experience in everyday life does not

ready to go," only to keep you waiting. Wolf points out that we can blame our daughters or husbands without thereby impairing our relationships with them; I think we can be angry with them without wanting to harm them.

${ }^{19}$ I thank an anonymous referee for the Journal of Ethics \& Social Philosophy for suggesting this example to me.

${ }^{20}$ For some empirical evidence of this, see Baumeister et al. (2007: 179).

21 Averill (1983: 1148). See also Averill (1982: 185ff.) for an overview of other such studies.

22 See Campbell and Muncer (2008) who argue that this difference is gendered. See also Tavris (1989: 36ff.) for more on the variety of ways we express anger and the narrow range that appears in much research on anger and aggression. 
involve a desire for harm or retribution, only that things turn out the way we expected or wished. An angry manager might simply desire that his employees arrive to work on time for once, an angry sports fan may simply want the Tigers to get to the playoffs, and an angry computer user may simply want his new software to work the way it is supposed to work. Anger involves a variety of desires, many of which do not involve the desire to harm or punish others.

\section{b. Anger is vicious because it is unpleasant or bad for us.}

A common strand in both Buddhist and Stoic thought is the idea that anger is bad because the experience is unpleasant. This kind of reasoning can be found in the eighth century Buddhist philosopher Sāntideva's The W ay of the Bodhisattva. ${ }^{23}$ It can also be found in Marcus Aurelius' Meditations. ${ }^{24}$ There is something to this; who, after all, wants to be that person stewing in their own anger after a traffic jam or bad customer service?

And yet, anger is not always unpleasant for everyone. After all, what counts as pleasant or unpleasant is largely a matter of taste. A Midwesterner might think that the pain and sweating caused by eating spicy food simply must be unpleasant, while someone from Sichuan may find the same experience quite enjoyable. One may well enjoy the thrill of anger; Carol Tavris quotes one respondent in a study on anger: "It wakes me up and makes me feel very much alive." 25 In a study on intermittent explosive disorder, characterized by extreme and disproportionate anger, of the 24 subjects interviewed, 18 reported relief with their aggressive acts and 11 reported feeling pleasure. ${ }^{26}$

It might seem that if we grant that anger is unpleasant for most of us most of the time, then anger in general is a vicious state. But being unpleasant is insufficient to make a state morally vicious. Grief over the loss of a loved one and chronic back pain are both unpleasant states, but that does not make them morally vicious.

Unpleasant states can even be morally virtuous: feeling guilty when one has broken a promise or disappointed when a friend misses a promotion is virtuous even though such feelings are unpleasant to experience. Being unpleasant may make an emotion undesirable in some respects, but it does not make it morally vicious.

One need not take anger to be unpleasant, however, to claim that it is bad for us. Many things - heroin, donuts, unprotected sex, and hitting the snooze button to name just a few - can be bad for us despite being pleasant. Perhaps, as other passages of Śāntideva suggest, anger is vicious not because it is often unpleasant, but because it is bad for either the one who gets angry (2004, BCA VI.7-8) or for the object of the anger (2004, BCA VI.11).27

23 Bodhicaryāvatāra, hereafter BCA, VI.5 and 24.

24 See XI.18.

25 Tavris (1989: 71).

${ }^{26}$ McElroy et al. (1998).

27 There is a small caveat in Śantideva's view as he does acknowledge that the anger of others can be beneficial as an opportunity to practice patience (2004, BCA VI.111). This seems to 
And yet, it is far from obvious that all anger really is bad for us or for others. There is interesting disagreement about whether or not some "healthy" anger can be good for us. Some empirical evidence suggests that people at least think it is not always bad: one study found that, even though many find anger to be unpleasant, a majority of both those who were angry (62 percent) and those who were the targets of anger $(70$ percent) rated episodes of anger as beneficial. ${ }^{28}$

As least in some serious cases, anger can be critically beneficial: think back to the woman angry with those who do not believe her about being sexually assaulted. Her anger might be beneficial by preserving her self-respect and preventing her from falling prey to the false consciousness of those who doubt what she experienced. In this case, her anger plays a crucial role in preserving things of moral value. ${ }^{29}$

Again, the deeper problem is that a state's being bad for us does not say much about whether it is morally vicious. Many states that are good for us are not thereby morally virtuous: having a knack for mental math or a strong immune system may be good for you, but they do not make you a morally better person. Many states that are bad for us are not thereby moral vices: having strong allergies or bipolar disorder can be bad for you, but such states are not morally vicious.

It is telling that moral virtues like honesty and generosity seem no less virtuous when they turn out to be bad for us. It is very sad if someone ends up being punished for their generosity, but their generous character still makes them morally better even though it was bad for them.

\section{c. Anger is vicious because it gets in the way of achieving our ends.}

Others have seen anger as vicious because it stands in the way of accomplishing our goals. Plutarch in his "On the Avoidance of Anger" offers the image of a child struggling to carve with a knife when his father takes it and easily completes the task. Like the child, says Plutarch, anger leaves us unable to be in control, unable to achieve our ends. ${ }^{30}$ Anger, on this view, is vicious because it is an obstacle to our goals.

One issue with seeing anger as vicious in this way is that it is unclear why it is vicious when it interrupts our bad goals. If I have the goal of hurting

suggest that anger can sometimes be beneficial, however this seems to be practical advice about how to deal with anger when confronted with it. There is no contradiction in offering this advice while at the same time thinking it would be better for everyone if there were no anger at all. See also McRae (2015), who denies that there is morally efficacious anger, but defends a Buddhist view of how anger can be beneficial via a process of transformation.

28 Averill (1982: 236). Similar results have been reported by Tavris (1989), DeAngelis (2003), and Tamir (2009).

${ }^{29}$ Relevant here is the discussion in Tessman (2005: 119ff.) on the value of anger. She helpfully points to Lorde (1984) on anger's role in preventing the hate many experience from being internalized as self-hate.

${ }^{30}$ Plutarch (2008: 55). 
someone's feelings or stealing from a store but am unable to do so because I am too angry, is my anger still vicious?

Bad aims aside, another problem with this claim about anger is that it seems to be false. At least some ends are better achieved when angry. Goals like fending off an aggressive bully or making it through the last mile of a marathon can be easier to achieve if one is angry. For many of us, anger can help in facing danger or intimidation or provide the sustained motivation to overcome fatigue. ${ }^{31}$ If this strikes you as too anecdotal, empirical research by Maya Tamir suggests that angry subjects performed better than calm subjects on "confrontational tasks" such as a computer game where the object is to defeat enemies. 32

This feature of anger is particularly relevant for political action. Malcolm $\mathrm{X}$ saw political ends like justice and equality as being, at least in many cases, aided by anger:

When I was in Africa, I noticed some of the Africans got their freedom faster than others. Some areas of the African continent became independent faster than other areas. I noticed that in areas where independence had been gotten, someone got angry. And in the areas independence had not been achieved yet, no one was angry.... Usually when people are sad, they don't do anything. They just cry over their condition. But when they get angry, they bring about a change. 33

Malcolm X's experiences in Africa led him to see goals like freedom and political change as better achieved though anger. Though anger may interfere with pursuing our goals in some cases, this is not always true and in some cases anger can even help to achieve them. ${ }^{34}$

\section{d. Anger is vicious by robbing us of control and interferes with reason.}

Related to the conception of anger as an obstacle is that of anger as an enemy of reason. This is a popular criticism that sees anger as interfering with our rational self-control. Here anger is vicious because it is cast as an external force that jumps into the driver's seat and steals control. Many Buddhist texts make this argument. For example, the fifth-century Indian Buddhist Buddhaghosa's influential Path of Purification and the canonical Kodhana Sutta refer to "falling prey to anger" and being "ruled by anger." ${ }_{55}$ This characterization of anger as an external force, one that takes over our minds and clouds our rea-

31 William Hazlitt, in his "On the Pleasure of Hating," makes a similar case for hate: "without something to hate, we should lose the very spring of thought and action. Life would turn into a stagnant pool, were it not ruffled by the jarring interests, the unruly passions of men" (2004/1826: 105).

32 See Tamir et al. (2008) and Tamir (2009).

33 Malcolm X (1965: 107).

${ }^{34}$ Jaggar (1989), for example, argues that the emotions of oppressed people can have special warrant and grant important epistemic insights. Tessman (2005) also emphasizes the value of anger to those under oppression. Bell (2005) gives a similar defense of the moral relevance of contempt.

35 Visuddhimagga, IX.15 and AN VII.60. 
son, is made explicit in The Dhammapada, one of the most famous Buddhist texts:

Whoever controls his anger, Is like a true charioteer.

In command of the rolling chariot

And not just holding the reins. ${ }^{36}$

This view of the viciousness of anger is not unique to Buddhism; Seneca offers a similar charge against anger: "Reason herself, who holds the reins, is only strong while she remains apart from the passions." ${ }_{37}$ Anger, so the challenge goes, is an enemy of reason that usurps power from us and so is always vicious.

One problem with this argument is that not everyone's experience of anger fits with this conception. Consider Martin Luther's description of his experience of anger:

I never work better than when I am inspired by anger; when I am angry, I can write, pray, and preach well, for then my whole temperament is quickened, my understanding sharpened, and all mundane vexations and temptations depart. ${ }^{38}$

Luther does not talk of falling prey to anger, but rather being inspired by it. He is not ruled by anger, but aided by it - he is more in control, less distracted and less tempted. If he were describing the effects of a drug, it would be used as a study aid by over-ambitious undergraduates and not those seeking to "tune out" and lose control.

But this account of the viciousness of anger suffers from a deeper error. It is a mistake to assume that "cool" reason always involves being in control and that "hot" emotions like anger always rob us of it. Consider Gita, a woman married to a man with a long-term pattern of physical and emotional abuse. ${ }^{39}$ Deep down, Gita wants badly to run away, not only for her own sake, but for the benefit of her young children. Even though Gita has calmly reasoned that she should stay with her violent husband for years, one day in a moment of anger she finally leaves him.

In this case, Gita's anger puts her more in control, better allows her to do what she knows she must do. In contrast with the picture in The Dhammapada, it is her anger that allows Gita to take the reins and regain control of her life. Anger is not always an external force that robs us of control, but is sometimes a manifestation of our deepest cares that puts us back in control.40

\footnotetext{
36 The Dhammapada, 17.2.

${ }^{37}$ De Ira, I.7.

${ }^{38}$ Luther (2004/1566: 206). This is from his Table Talk, no. 318.

${ }^{39}$ Here I am adapting an example from Nomy Arpaly (2004: 44) for my own purposes.

${ }^{40}$ Campbell and Muncer (2008: 285) argue that how we experience anger and control is often gendered. According to them, men more often experience expressing anger as a means of asserting control while women are more likely to experience it as a loss of control.
} 


\section{Anger and Care}

It is possible, however, to accept that Gita's anger better achieves her goals without giving her more control. After all, if someone broke into her home and carried her and her children away, that might achieve what she really wanted without thereby putting her in control. ${ }^{41}$ There is, however, a respect in which Gita's anger is different from being carried off by a well-meaning stranger. Whether or not Gita's anger gave her more control, her anger manifests her deepest concerns - for her own wellbeing and the wellbeing of her children - in a way that being carried off does not.

Emotions such as anger, rather than calm reasoning, often better manifest what matters to us. Regardless of its effect on her control, Gita's anger manifests what she really cares about in a way that her calm reasoning does not. It is her calm and emotionless rationalizations that seem pathological and removed from what she cares about and her anger that manifests her deepest concerns. Central to the account I am offering is the idea that anger can manifest our deeply held moral cares and concerns. This picture of anger is in contrast with those who see it as essentially pathological, seeing anger as like cancer or a brain tumor. On this way of seeing anger, it is an external intruder that no more manifests our cares and concerns than a seizure or the flu does.

So even if it were true that anger always lessens our self-control, it could still manifest our cares and concerns. Harry Frankfurt famously described what he termed "volitional necessity" - when a person is unable to act contrary to her deepest convictions. Frankfurt cites Martin Luther's famous declaration, "Here I stand; I can do no other." 42 In this situation, Luther has less control, he cannot help but be compelled to act the way he does, but his lack of control is not a result of an external intruder but of his deepest convictions. Similarly, I might have less control over my behavior because I am compelled by compassion to help someone who has slipped on the ice in a parking lot. Even though it lessens my control, my compassion is not simply pathological; it is a result of a concern for others that is my own.

One can be in a similar situation with anger: upon seeing an unjust law enacted or hearing of a person being tortured, one might feel righteous indignation out of emotional necessity. Someone may find herself saying, like Luther did, "Here I feel; I can feel no other." Such anger may force itself upon us and still manifest our deepest cares and concerns. ${ }^{43}$

Anger often manifests what we care about. Richard is angry that the Red Sox have lost the World Series because he cares about the team doing well. Julia is angry that she must work on Christmas because she cares about celebrating the holiday with her family. By contrast, someone who does not care

41 Thanks to Jay Garfield for this variation.

${ }^{42}$ Frankfurt (1998: 86).

${ }^{43}$ This dovetails nicely with a picture of the virtuous agent as acting naturally, spontaneously, or automatically. This ideal can be found recently in Doris (2015). It can also be found in the classical Chinese philosopher Zhuangzi's ideal of effortless action or wu-wei; see Slingerland (2003) and Velleman (2008) for helpful discussion. 
about American sports or Christian holidays is unlikely to be angry in similar situations because these things just do not matter to her. This does not mean that caring about something always involves getting angry; a very calm person may care very deeply about politics but never get angry about it. Getting angry, however, does seem to require that one care about something.

Concern, however, is not just a precondition for anger - anger is a manifestation of what matters to us. This allows it to say something about what kind of person we are, as is clear in cases where people flaunt their anger: some prescriptive grammarians emphasize their anger over semicolon misuse because it shows not only an awareness and sensitivity to the rules of English grammar, but also that they are the kind of person who cares about such rules.

The nature of this caring can be very difficult, if not impossible, to know. Suppose that Simon is angry because he failed to land a promotion at his company. He may be angry for a variety of reasons: because he cares about making more money, because he cares about impressing his emotionally distant father, because he cares about how others in the company see him, because he cares about his career proceeding in the way it is "supposed" to proceed, because he cares about having a greater influence in the direction of the company or any combination of these. Simon, like the rest of us, has many different cares and concerns, many of which play a role in his emotional life. My claim that anger is related to our cares is not meant to suggest that there is a simple or easy answer to how to tell which cares are relevant to a person's anger in real life.

\section{Virtuous and Vicious Anger}

Anger, then, often manifests what we care about. When these cares are for moral goods like the rights and wellbeing of others, the anger reflects well on one's moral character. When anger manifests a lack of concern or immoral concern such as malice, contempt, or ill will toward them, then it is morally vicious. ${ }^{44}$

As the anger of Malcom $\mathrm{X}$ and Gita suggest, the cares and concerns manifested by anger can often be moral in nature. Our anger at the carelessness of a drunk driver can manifest a concern for safety (often both of others on the road and the drunk driver). Anger at government censorship can manifest a concern for free speech. Anger at political corruption and prejudiced laws can manifest a concern for fairness and racial equality.

Anger is by no means the only way such concerns can manifest, but when it does manifest such concerns it reflects well on one's moral character. I began with a stereotypical view of moral exemplars like Mother Teresa as being calm and free from anger. This seems true with regard to anger born of selfish

${ }^{44}$ See also West (2016) and DeYoung (2009), who note that anger can be an expression of concern. Bell (2015) defends contempt as morally good on a variety of grounds. I have a narrower, Kantian sense in mind here. 
and trivial concerns, but not of anger that manifests moral concern. Consider Mother Teresa's own report about feelings of anger and frustration:

Am I ever angry or frustrated? I only feel angry sometimes when I see waste, when things that we waste are what people need, things that would save them from dying. Frustrated? No, never. ${ }^{45}$

The anger Mother Teresa admits to experiencing does not make her a morally worse person, because it is quite different from the anger we experience when waiting in a traffic jam or when someone insults us. This anger is rooted not in selfish concerns but in care for the wellbeing of others - this is why such anger not only fails to detract from her moral character, but reflects well on it.

When anger manifests moral concern, it reflects well on one's moral character. When anger manifests moral indifference or selfish concerns, it reflects poorly. Anger is virtuous or vicious by the underlying concerns that it manifests. So when anger manifests a concern for the wellbeing of others or for justice, it is virtuous. When someone's anger manifests a contempt or a concern to see the other harmed, it is vicious. As we have seen, anger can manifest a variety of concerns all at once (recall the various concerns that Simon's anger manifested) so it may be more accurate to say that anger is virtuous to the extent that it manifests morally important concerns.

It might seem strange to claim that anger that manifests moral indifference is vicious. After all, sometimes anger manifesting a lack of moral concern does not seem vicious at all. Suppose that, at work at least, Kelly cares only about his own self-interest regarding his clients. Though he cares about people not being humiliated in general, his co-workers are cruel and he does not care about whether or not they are humiliated. One day a particularly awful colleague causes a scene and their boss mildly humiliates them in order to prevent the situation from getting worse. Kelly gets angry at his co-worker, primarily because of his interest in doing business smoothly. Here it can seem that Kelly's anger is not vicious even though it is insensitive to important moral considerations. 46

We must be careful here. The fact that Kelly's anger manifests a concern for his own financial interest in the client's service need not make it vicious. What would make it vicious is if it also manifests a lack of concern for his coworker's humiliation. Insofar as he seems to have a moral blind spot about the wellbeing of his co-workers, it does seem to reflect poorly on him. Caring about people not being humiliated in general, but not caring about one's coworkers being humiliated is a bit like caring about the rights of people in general, but not caring about the rights of women. Someone who cares about the wellbeing of people in general, but not the wellbeing of the homeless in their town has a blind spot in their moral concern. Insofar as Kelly's anger manifests a similar blind spot of concern, it reflects poorly on his moral character.

45 Mother Teresa (1996: 385).

46 Thanks to an anonymous referee at the Journal of Ethics \& Social Philosophy for this objection and example. 
This is not to say that it is necessarily vicious to be angry with the coworker. Overall moral evaluations are difficult and it can be very difficult to weigh various factors. We would expect a moral person to be concerned with all of the various participants: the client, co-worker, boss, and oneself. A moral person will also care about the situation not escalating, about the damaging fallout of such a scene to people's emotions and to their ability to have a peaceful life and support their families. Someone in Kelly's position could experience anger toward the co-worker that manifests these concerns. But insofar as Kelly's anger manifests only his business self-interest, it reflects poorly on his moral character - his anger does not manifest any morally good concerns and manifests a lack of various moral concerns. ${ }^{47}$

If this still strikes you as too counterintuitive, it is worth noting that not all vicious states are seriously vicious. Kelly's anger need not make him a bad person overall to count as vicious. The anger might simply be slightly vicious - it would be slightly more virtuous if his anger also manifested a concern for his co-worker. And even if the anger is vicious, it may be a rare lapse for him. Overall character evaluations are made over time and we can imagine a good friend saying, 'Yeah, Kelly getting mad in the meeting doesn't really reflect well on him, but he's not really a bad person. His emotions usually do come from a place of concern for everyone."

If, however, Kelly really does care about his colleagues not being humiliated, but this concern is not manifested in this particular episode of anger, then his anger is not morally vicious. It is neither virtuous nor vicious; it just does not say much either way about his character. Anger is vicious by manifesting a lack of concern. As I will argue, a concern's failure to manifest as anger is not vicious since a variety of factors irrelevant to moral character affect how and when our concerns manifest emotionally. Though it is, for most people, psychologically unlikely to care about your co-workers and not get angry when they are humiliated, if Kelly really does care deeply about his coworkers, the failure of this concern to manifest as anger does not make him morally worse.

It is worth noting that, though anger can sometimes be a manifestation of care, this does not vindicate the dubious claims of abusive husbands that their rage shows how much they care. Everyone knows that the clichéd I-hit-herbecause-I-love-her excuse is complete nonsense because it is easy to see that what the abuser really cares about is malicious: domination and entitlement over another person. Lundy Bancroft, a therapist specializing in domestic abuse, makes this very clear:

\footnotetext{
${ }^{47}$ Kelly is, in some respects, like Kant's prudent grocer who charges fair prices only because it is good for business. Though he does what a moral person would do, it does not reflect well on him since he does it for the wrong reasons. So, though a virtuous person might also feel anger at the co-worker, her anger will reflect well on her because it manifests very different concerns. An Aristotelian might describe Kelly's anger as "emotion in accordance with virtue" rather than as a "virtuous emotion."
} 
An abusive man often tries to convince his partner that his mistreatment of her is proof of how deeply he cares, but the reality is that abuse is the opposite of love. The more a man abuses you, the more he is demonstrating that he cares only about himself. He may feel a powerful desire to receive your love and caretaking, but he only wants to give love when it's convenient. 48

The abuser's excuse is bullshit not because anger cannot manifest concern, but because the kind of anger associated with abuse manifests an altogether different concern - for domination, control, and self-gratification. ${ }^{49}$

\section{Fittingness, Proportion, and Care}

If the moral virtuousness or viciousness of anger really is determined by the cares and concerns it manifests, then it follows that anger can be virtuous even when it is out of proportion or not fitting for the situation. These can seem to be counterintuitive results, so it is worth discussing how my account treats them. ${ }^{50}$

Let us start with anger that manifests moral concern but is disproportionate to its object. Recall the case in which Kelly's boss humiliates one of his coworkers who is causing a scene at work, knowing that this mild humiliation will prevent the situation from escalating. Let us suppose that, this time, instead of being only concerned for his own relationship with the client, Kelly actually cares very much about his co-workers not being humiliated. This time, when the boss mildly humiliates a co-worker, Kelly gets very, very angry. Kelly is absolutely livid over this mild humiliation, anger that really does manifest a genuine moral concern for his co-workers. Even though it manifests moral concern, isn't Kelly's extreme anger vicious (or at least non-virtuous) because it is out of proportion to the badness of what happened?

It is important to keep in mind that the issue here is how intense Kelly's anger itself is, not how intense his expression of it is. Picturing Kelly livid over the humiliation of his co-worker leaves open how he expresses it - he could keep it to himself or he could be yelling and shouting at his boss. Questions about expressions of emotion are separable from questions about whether emotions themselves are virtuous; recall that even those who think all anger is vicious can accept that it can be virtuous to express anger.

It is also important to distinguish the intensity of Kelly's anger from the intensity of his concern. ${ }^{51}$ Seneca offers a practical reason to avoid matching the intensity of one's anger to the degree of badness: "If you want the wise man to be as angry as the atrocity of men's crimes requires, he must not mere-

48 Bancroft (2002: 60).

49 See also Ben Ze'ev and Goussinsky (2008).

${ }^{50} \mathrm{I}$ again thank an anonymous referee at the Journal of Ethics \&o Social Philosophy for raising the issues discussed in this section and for providing the cases of Bill and Kelly.

51 I am rejecting here a view defended by Hurka (2001: 83ff.), who argues that one's attitudes should be proportionate to the intrinsic goodness or badness of their object. Cogley (2014)

also endorses this claim about anger more specifically. 
ly be angry, but must go mad with rage." 52 If the virtuous person's anger must be proportionate to the badness in the world, then all morally virtuous people will be completely, insanely livid all the time.

Instead, what matters for his moral character is that Kelly's concern is proportionate to the situation, not the intensity of the anger itself. This is because a wide variety of factors affect the intensity of our emotions, many of which do not say much about our moral character. One's anger might be more intense because it is a particularly hot and humid day, because one is going through a tough divorce, because one's culture has normalized more intense anger, or because one simply has a more intense emotional life across the board. These things do not make one a morally better or worse person - they are features of one's character but not necessarily of one's moral character.

More intense anger does not always mean a greater degree of concern. Of two students who receive a failing grade on an exam, we cannot know that one cares more about his grades simply because he is angrier. One student might be less angry because he expected to fail, while the other foolishly thought he would pass with flying colors. One might be angrier because he is exhausted and over-caffeinated or because his parents are currently getting a divorce. There can also be interpersonal differences in temperament; the less angry student may simply experience less intense emotions overall. More anger can be the result of more concern, but it is not always.

There can also be cases in which anger manifests moral concern, but is not fitting for the situation and so can seem less than virtuous. ${ }^{53}$ Consider Bill, a kindergarten classroom assistant, who cares an enormous amount about the children having stimulating educational experiences. As a result, Bill gets extremely angry whenever such an opportunity is lost. So when the teacher decides not to play an educational game on the bus because she knows it would rile up the students too much, Bill get very angry. Being angry is not a fitting response, but since it manifests a good concern, it turns out to be virtuous on my account.

Insofar as his anger manifests a concern for the students' learning, Bill's anger does seem to reflect well on him. He is, after all, mad because he cares about something that really is good. He is, for example, a morally better person than someone who is angry because not playing the game means one fewer line on his résumé. It is extremely likely, however, that Bill's anger also manifests a lack of concern for other goods, like the safety of the children (if they get too rowdy there could be an accident) or the wellbeing of the teacher (she may be exhausted and overworked). Bill's anger is likely vicious not because it is not fitting, but because it manifests a lack of morally relevant concerns.

We expect a virtuous person to care about a sufficiently wide range of moral goods. Kelly's intense anger at the humiliation of his co-workers may

${ }^{52}$ De Ira, II.9.

${ }^{53}$ Again, I am disagreeing here with a number of theorists who take fittingness to be a necessary condition for virtuous anger. See, for example, Cogley (2014) and Bell (2009). 
very well suggest a lack of concern for the damage that would be done if the situation is not diffused. In general, intense anger at a narrow range of wrongs suggests that one overvalues those wrongs at the expense of other, equally important wrongs. If this is the case with Kelly, then his intense anger might reflect well on him insofar as it manifests a concern that people not be humiliated (it is better than if, as before, it manifested a self-interested concern for his sales) but also might reflect poorly on him in that it manifests that he cares too little about other morally important things. ${ }^{54}$

It is also worth keeping in mind when thinking about these cases that real people rarely experience particular emotions in isolation. Given a sufficiently wide range of concerns, we expect that Bill's and Kelly's anger will be tempered by other emotions that result from caring about other important aspects of their situations.

\section{Righteous Indignation}

If anger seems to be vicious in general, it is because it is very often selfcentered. If you try to recall the last time you were angry, it was likely the result of either a personal insult or of not getting what you wanted when you wanted it. It is revealing that these are the primary methods that psychologists use when they want to reliably induce anger for study. ${ }^{55}$ Many theorists claim that all anger is egocentric in some way, that it requires a perceived harm to you and yours. 56 Much anger is self-regarding in that it grows out of our concern for our own reputations and the satisfaction of our own desires. When a colleague makes me look foolish at a conference, I get angry because it conflicts with a particular image I have of myself as intelligent, an image I like quite a bit. There is often something selfish about the focus on my own reputation and thinkers like Sāntideva and Gabriele Taylor rightly locate the viciousness of many cases of anger there. ${ }^{57}$

Though some anger is vicious because it manifests a self-centered orientation, this does not make all anger vicious. As Taylor herself points out, selfimportance and contempt for others can result in a failure to become angry. ${ }^{58}$ An arrogant teacher might not get angry with his students because he does not put any weight on the opinions of "stupid kids." A particularly self-centered person can fail to get angry at personal slights because he rarely places weight on anything others say at all. Anger can manifest self-centered concerns, but so can its absence.

${ }^{54}$ I defend this general view of virtuous emotions and the claim that irrational emotions can be virtuous in more detail in Bommarito (forthcoming).

55 See Tavris (1989: 165).

56 For example, Ben-Ze'ev (2000: 381) describes it as a response to a perceived harm to you or what you care about and Śāntideva (2004, BCA VI.62-3) takes anger to be based on selfgrasping.

57 Taylor (1975: 80).

58 Ibid.: 397. 
More importantly, anger is not always self-regarding. We can be angry because of harms suffered by others not related to us. Contrary to Aristotle's account, we can be angry with those who are far away or dead. ${ }^{59}$ When my father reads about a gang rape in Delhi, he becomes very angry, even though he has never been to India and has no personal connection to the victim. Reading accounts of American slavery can make one's blood boil, despite the fact that all involved are long dead.

This is close to what Peter Strawson calls "indignation" - a "vicarious attitude" where "one's own interest and dignity are not involved." ${ }_{00}$ I will use "indignation" in a slightly different sense from Strawson. While it is more independent from our own interests than anger rooted in frustration or pride, it is not completely independent of our own interests and dignity. I will use the term to refer to anger that stems from a concern for rights, justice, or fairness. This does not mean that indignation cannot involve one's own interests or dignity. Though John Rawls famously pointed out that justice involves bracketing our personal interests in many ways, this does not mean that it is completely independent of one's own interests. After all, my concern that everyone be treated fairly entails a concern that I myself am also treated fairly. I am, after all, a person, too. ${ }^{61}$

Indignation, then, is anger that manifests a concern for rights or justice. But even indignation can fail to be morally virtuous: anger that manifests a concern for rights is not always morally virtuous and need not be moral at all. A member of the aristocracy in a feudal country, for example, may feel indignation because her legal right to take the property of her subjects has been denied. Or suppose I am a member of a club with inegalitarian rules that favor me - say I get an extra portion at dinner. When I am denied a second helping of steak, I may become indignant because the rights bestowed on me by the rules of the club have been denied, though I have no moral right to more food than anyone else.

Righteous indignation, then, is not a redundant phrase - to count as righteous, indignation must be anger that manifests concern for moral rights. Such indignation manifests a concern for the wellbeing of others and for fairness and so reflects well on one's moral character. To feel righteous indignation over human trafficking is virtuous because it manifests concern for the rights and wellbeing of others, a morally important concern.

Those who condemn all anger can have a difficult time explaining why righteous indignation is vicious. Consider Plutarch's attempt in his "On the Avoidance of Anger":

${ }^{59}$ See Rhetoric, $1380 \mathrm{~b} 25$.

60 Strawson (1962: 84).

${ }^{61}$ For more on this, see Thomas Hill's "Servility and Self-Respect" (1991) where he highlights the moral importance of a concern for one's own rights. The Buddhist version of this point would be to note that a concern for the suffering of all sentient beings entails a concern for what would conventionally be called "my" suffering since " $\mathrm{I}$ " am also a sentient being. Other philosophers, notably Taylor (1975: 90), have also thought that indignation can be felt on one's own behalf. 
[A]nyone who is commonly susceptible to anger because of genuine righteous indignation must rid himself of the excessive, unmitigated part of his anger, along with his overconfidence in the people he comes across. ${ }^{62}$

Someone who experiences such indignation must get rid of not the emotion itself, but the excessive part and his overconfidence, neither of which seem essential to the emotion. When confronted with reliable evidence of great evils, intense indignation reveals that one cares about moral goodness. Consider the story of Elie Wiesel, reported by Martha Nussbaum:

Wiesel was a child in one of the Nazi death camps. On the day the Allied forces arrived, the first member of the liberating army he saw was a very large black officer. Walking into the camp and seeing what was there to be seen this man began to curse, shouting at the top of his voice. As the child Wiesel watched, he went on shouting and cursing for a very long time. And the child Wiesel thought, watching him, now humanity has come back. Now, with that anger, humanity has come back. ${ }^{63}$

Nussbaum concludes, "In circumstances where evil prevails, anger is an assertion of concern for human well-being and human dignity." The officer's indignation at the horrors he discovered manifests morally important concerns for human life and dignity and so reflects well on his moral character. Plutarch's suggestions do not seem to apply in the face of such blatant evil. The soldier seems neither to be overconfident nor does his anger seem excessive. As another commentator, describing the indignation of those who liberated German death camps, puts it: "No doubt the gesture was not lost on the survivors. Finally, someone cared enough to be angry." ${ }_{64}$

It is hard to find pure cases of righteous indignation in real life. Nonmoral anger and righteous indignation often mix and can be hard to distinguish. Consider an example from everyday life. I am waiting in line at a crowded grocery store and someone intentionally cuts in front of me. I feel what could rightly be described as indignation - I am angry because someone knowingly did something unfair and did not respect my rights. My indignation manifests a concern for fairness, a morally important concern, albeit on a small scale. That is not, however, all that it manifests. It is mixed with an everyday, nonmoral anger, too. It also manifests personal, nonmoral concerns: the frustration that $I$ am disadvantaged and inconvenienced; now $I$ will get home later and, even worse, I have been personally insulted.

Contrast this case with how I am apt to feel if this person intentionally cut in front of the person in the line next to me. I would still be indignant, but nowhere near as much as if it were to happen to me. So it looks like when someone does cut in front of me, this small amount of anger is genuine indignation that manifests morally relevant concerns. The rest is simply run-of-themill anger that does not manifest morally important concerns and so is not

62 Plutarch (2008: 65)

${ }^{63}$ Nussbaum (1994: 403).

${ }^{64}$ Cunningham (2005: 269). 
morally virtuous. ${ }^{65}$ Self-regarding anger and righteous indignation often mix and, when they do, it is only virtuous to the extent that one has genuine righteous indignation.

It may be objected here that perhaps the affective aspect of indignation makes such morally good concerns less effective in some ways - less pleasant or less able to be directed in useful ways. To what extent the affective aspect is pleasant or useful is an empirical question and liable to vary greatly between individuals. Some people may be held back by their feelings of indignation while others may be empowered and motivated by them. For now, recall that whether or not it is useful, pleasant, or beneficial, righteous indignation can manifest morally good concerns and so reflect well on one's moral character. Anger can be bad in this way, by influencing behavior, but it can also be virtuous without any associated behaviors - someone who is completely paralyzed can feel righteous indignation without overt behavior at all.

Perhaps, however, indignation involves some danger to moral concern itself. Righteous indignation, even if virtuous, can still be morally dangerous. Indignation can change how we relate to its object. When I have righteous indignation at a CEO who embezzled the retirement money of his employees, I am in danger of coming to see him only as a perpetrator of injustice. I run the risk of no longer relating to him as a full-blooded human. For Śāntideva, anger is a "root-cutting fault" partly for this reason; in changing how we relate to the object of our indignation, it jeopardizes the very source of our compassion. ${ }^{66}$ Nussbaum offers a similar criticism of indignation: it expresses and reinforces contempt for the object and a blindness to our own faults. ${ }^{67}$ This change in relation to the object can, and for many of us often does, accompany righteous indignation, but it is not an essential part of it.

It is important here to distinguish moral theory from practical advice. Buddhists and Stoics are often in the business of offering practical advice. When Seneca writes, "it is easier to banish dangerous passions than to rule them," he is giving good advice - we should be careful of anger because it has the power to carry us away. ${ }^{68}$ But being dangerous is not the same as being vicious. Spending time with friends that are a bad influence on me may be dangerous, it may be morally safer for me to avoid them altogether, but that does not mean spending time with them is in itself vicious.

There can still be a variety of nonmoral reasons to avoid many types of anger. It seems no accident that Buddhism and Stoicism are both traditions that place a high value on tranquility and peace of mind. Being angry involves agitation and so is an enemy of tranquility; this seems to be behind at least some of Śāntideva’s advice:

So whether friend or foe,

65 This example is inspired by Śāntideva (2004, BCA VI.62-3).

${ }^{66}$ See Cozort (1995) for more discussion of anger as "cutting the roots" of virtue.

${ }^{67}$ Nussbaum (1994: 424). See also the discussion of anger and "road of status" in Nussbaum (2016).

${ }^{68}$ De Ira, I.7. 
If you see someone do wrong,

Think, "This is because of conditions"

And you'll become happy. ${ }^{69}$

Here, the reason to avoid anger is not because it is immoral, but because it gets in the way of our happiness. Seneca seems to have a similar notion of "vice" in mind when he calls anger vicious: "Virtue alone is lofty and sublime, nor is anything great which is not at the same time." ${ }_{70}$ But tranquility is not the same as moral virtue. An anxious person is not an immoral person even though she experiences a less tranquil inner life.

Indignation does not necessarily bring contempt with it and the criticism partially rests on assumptions about how many emotions we can hold in our hearts at once. A virtuous person may feel indignation when confronted with injustice, but that will not be the only emotion she feels. When a parent must punish a child or when we must rebuke a friend, most sensitive people feel a stew of emotions: anger over the transgression, regret of not having done more to prevent it, sadness at the pain that the punishment or rebuke will cause, and hopeful that such a situation will not occur again. A virtuous person may well feel both indignation and compassion; Christians advocate something similar with the familiar "hate the sin, love the sinner" advice. ${ }^{71}$ One does not rule the other out; rather, both manifest important concerns.

\section{Anger Is Not Required to Be Morally Virtuous}

So far, I have argued that some types of anger can be morally virtuous. This does not mean that experiencing such anger is required for being morally virtuous. I have only argued that when we experience some forms of anger, such as righteous indignation, it can be virtuous. I have not argued that all virtuous people will feel righteous indignation nor that all failures to experience righteous indignation in a situation that warrants it are morally vicious. I have not argued for these claims because I think they are false.

Which emotions we experience is a complex matter involving brain chemistry, culture, and individual temperament. An Allied soldier who does not feel angry when he discovers a Nazi death camp may care about human suffering just as much as the one who gets intensely indignant. Perhaps this soldier is too stunned to feel anything at all or becomes hyper-focused when under great stress. Or perhaps his concern is expressed in other emotions, like sadness, despair, or cold scorn. Righteous indignation involves morally important cares and concerns, and so is virtuous. But it is not the only way that such cares and concerns can manifest emotionally.

69 Śāntideva 2004, BCA VI.33. I discuss this interpretation of Śāntideva in more detail in Bommarito (2011).

70 De Ira, I.27.

${ }^{71}$ See also Westlund (2009), who argues that forgiveness does not require eliminating anger, but rather contextualizing it and not being absorbed by it. 
One might worry here that anger not only manifests that one cares about certain things, but also how one cares. This seems to suggest that there is a unique, right way to manifest care, and that sometimes anger is the only correct response. After all, perhaps being shocked manifests a naiveté about how awful people can be or perhaps sadness or despair manifest a retreat from injustice.72

Though there are right and wrong ways to manifest concern, most of the time there is not a single correct one. This is because what makes something $a$ right way to manifest concern emotionally depends on many factors about a person's experience, temperament, culture, and mental life. Being stunned may be naïve for some, but not for others - after all, one might have different evidence about how bad people can be. For a sheltered young person recently shipped off to war, being too stunned to feel anything makes perfect sense and does not reflect poorly on their moral character at all. For a wellexperienced soldier, things may be different. Beings sad might manifest a cowering from injustice for some, but not for everyone. It might, for example, simply manifest a high degree of empathy for the suffering of others. ${ }^{73}$

Nevertheless, it is possible for anger to be the only virtuous response for people in certain contexts with certain mental and emotional lives. This is not because of anything special about anger or its fittingness. Instead, it is because, given the situation and psychological facts about the person, anger will be the only way the morally relevant cares will manifest. Another person with the same degree of concern may well manifest it as a different emotion or fail to manifest it emotionally at all, not because morality matters less to them, but because of a variety of morally irrelevant factors about their culture, personality, and situation.

I have given an answer to the question, "How does anger relate to our moral character?" I have not, however, attempted to answer the question, "How angry will a morally good person be?" Asking this question is a bit like asking, "How animated will a good conversationalist be?" or "How colorful will a good painting be?" These are questions with no answer. There is no correct answer to these questions because there is a plurality of ways to be good in this respect, many of which will depend on one's culture and personality. Some paintings are good without any color at all, while other equally good paintings are full of color. Some people are good conversationalists by being very animated and others are good conversationalists by quietly engaging their partner. Though all morally virtuous people will have certain cares and concerns, in some this will manifest as indignation and in others it will manifest in other ways.

This means that one can be fully virtuous without getting angry, even when anger would be fitting, as long as this does not manifest a lack of con-

72 I thank another anonymous referee for the Journal of Ethics \& Social Philosophy for raising this issue.

${ }_{73}$ Pereboom (2009), for example, argues that anger can be replaced by sadness without a loss of resolve. 
cern for the moral goods at stake. Other things being equal, for most of us, caring about something means being disposed to get angry in certain circumstances. But in messy old real life, other things are rarely equal. Someone on a mood-altering drug may no longer be disposed to feel anger at all, though she still cares deeply about moral goods. For someone with an extremely calm temperament, caring deeply about something may not induce anger at all.

So, for example, a very high-level Buddhist practitioner or Stoic sage can still care deeply about moral goods despite never getting angry at all. ${ }^{74}$ Such people can still care about moral goods and will, for example, still try to eliminate injustice despite no longer feeling any anger. This may well turn on a particular picture of an ideally virtuous person as having a mental and emotional life free from many states we often take to be good in certain situations. 75

Another way to see this is to think about how not all failures to have emotions are a result of a lack of concern. One way this can happen is from personality differences. For some people, a failure to feel jealous manifests a lack of concern for the relationship, but others "aren't the jealous type" and a lack of jealousy does not mean that they do not care about their relationship. In the same way, for some people, failing to get angry about injustice means they do not really care about it. But others can care very deeply without any anger because they simply have a calm temperament.

If all I know is that someone is morally virtuous, I do not know whether they are on a newly prescribed sedative or going through a divorce or struggling through chronic fatigue. Such things can affect the emotions someone experiences without affecting the depth of their moral concern. These things can result in a failure to experience virtuous emotions like moral indignation. Even though it would be virtuous if they felt it, failing to feel it does not make them morally worse. Being exhausted or stressed does not make someone a morally worse person and drug companies need not list "moral vice" among the side effects of their sedatives. ${ }^{76}$

Perhaps more importantly, morally virtuous people need not be emotional clones of one another. One is a morally worse person by caring less about

\footnotetext{
${ }^{74}$ It is worth noting that Buddhists and Stoics might soften their view to allow that one can be overall virtuous despite feeling anger. Overall assessments of virtue are complex and they might simply claim that in absolutely ideal cases, one will not experience any anger. These views can also allow that there are more and less destructive or vicious ways of manifesting concern; even if they take anger to be categorically vicious, this does not entail that all anger is vicious to the same degree.

75 So, for example, if anger is necessary for blame, then it will turn out that on these views an ideally virtuous person will not blame others. See Wolf (2011) for the idea that blame entails anger and Sher (2005) for a defense of blame as morally important. I am sure that many Stoics and Buddhists would not shrink from the idea that ideal beings do not blame others. I thank an anonymous referee at the Journal of Ethics \& Social Philosophy for bringing this to my attention.

${ }^{76}$ Again, see the very illuminating discussion in Seidman (2016) about how emotional dispositions associated with caring can be masked and so fail to manifest.
} 
moral goods, not simply by having a calm temperament. ${ }^{77}$ If all I know about a painting is that it is aesthetically good, I do not thereby know how colorful or abstract it is. If all I know about someone is that they are a morally virtuous person, there is much I do not know about them. I do not know whether they are tall, clever, boring, or funny. I also do not know whether they are optimistic, calm, or animated. The emotional lives of morally virtuous people, like good paintings, admit of a variety of modes. This does not mean there is no such thing as a good painting, but it does mean we should be careful of picking surface features of paintings we know to be good and assuming that all good paintings must share those features.

Anger is made morally virtuous or vicious by the underlying concern it manifests. Understanding anger's relation to moral character in this way best explains when it reflects well, poorly, or not at all on someone's moral character. This understanding of anger and moral character allows for emotional variation among virtuous people and respects the variety of forms that anger takes. We get angry because we care about something. Sometimes what we care about is selfish and sometimes it is even immoral. Other times, however, what we care about is a moral good - justice or the wellbeing of others. In those cases, our anger is morally virtuous. ${ }^{78}$

Nicolas Bommarito

University of Buffalo

Department of Philosophy

npbommar@buffalo.edu

${ }^{77}$ In his discussion of caring, Seidman (2016) argues that caring does not entail specific emotional dispositions, only dispositions to attend and to respond. Other emotional dispositions associated with caring are derivative of these and so can be blocked or altered. I defend the same claim in Bommarito (forthcoming).

${ }^{78}$ I am grateful to Nomy Arpaly, Derek Bowman, David Estlund, Jay Garfield, Alex King, Karsten Struhl, and three anonymous referees for the Journal of Ethics \& Social Philosophy for insightful comments. I also received helpful comments on earlier drafts presented at the National University of Singapore and the Cogut Center for the Humanities at Brown University. 


\section{References}

Adams, R. M. (2006) A Theory of Virtue: Excellence in Being for the Good, Oxford: Oxford University Press.

Aristotle (1999) Nicomachean Ethics, T. Irwin, trans., Indianapolis, IN: Hackett Publishing.

Arpaly, N. and Schroeder, T. (2016) In Praise of Desire, New York: Oxford University Press. (2004) Unprincipled Virtue, Oxford: Oxford University Press.

Aurelius, M. (2004) Meditations, M. Staniforth, trans., New York: Penguin Books.

Averill, J. R. (1983) "Studies on Anger and Aggression," American Psychologist 38(11): 1145-60. (1982) Anger and Aggression: An Essay on Emotion, New York: Springer-Verlag.

Bancroft, L. (2002) Why Does He Do That? Inside the Minds of Angry and Controlling Men, New York: Putnam.

Baumeister, R., Vohs, K. D., DeWall, C. N. and Zhang, L. (2007) "How Emotion Shapes Behavior: Feedback, Anticipation and Reflection, Rather Than Direct Causation," Personality and Social Psychology Review 11(2): 167-203.

Bell, M. (2015) Hard Feelings: The Moral Psychology of Contempt, New York: Oxford University Press.

(2009) “Anger, Virtue and Oppression," in L. Tessman, ed., Feminist Ethics and Social and Political Philosophy: Theorizing the Non-Ideal, New York: Springer, pp. 165-83.

(2005) “A Woman's Scorn: Toward a Feminist Defense of Contempt as a Moral Emotion," Hypatia 20(4): 80-93.

Ben-Ze'ev, A. (2000) The Subtlety of Emotions, Cambridge: The MIT Press. and R. Goussinsky (2008) In the Name of Love: Romantic Ideology and Its Victims, New York: Oxford University Press.

Bommarito, N. (forthcoming) Inner Virtue, New York: Oxford University Press. (2011) "Bile and Bodhisattvas: Śāntideva on Justified Anger," Journal of Buddhist Ethics 18: 356-81.

Buddhaghosa. B. (1999) The Path of Purification: Visugghimagga, B. Nanamoli, trans., Onalaska, WA: BPS Pariyatti.

Campbell, A. and Muncer, S. (2008) "Intent to Harm or Injure? Gender and the Expression of Anger," Aggressive Behavior 34: 282-93.

Charland, L. C. (1997) "Reconciling Cognitive and Perceptual Theories of Emotion: A Representational Proposal," Philosophy of Science 64(4): 555-79.

Cogley, Z. (2014) "A Study of Virtuous and Vicious Anger," in K. Timpe and C. Boyd, eds., Virtues and Their Vices, New York: Oxford University Press, pp. 199-224.

Cozort, D. (1995) "Cutting the Roots of Virtue: Tsongkhapa on the Results of Anger," Journal of Buddhist Ethics 2: 83-104.

Cunningham, A. (2005) "Great Anger," The Dalhousie Review 85(3): 353-69.

Dalton, J. P. (2011) The Taming of the Demons: Violence and Liberation in Tibetan Buddhism, New Haven, CT: Yale University Press.

DeAngelis, T. (2003) "When Anger's a Plus," Monitor on Psychology 34(3): 44-45.

DeBrabander, F. (2004) "Psychotherapy and Moral Perfection," in S. Strange and J. Zupko, eds., Stoicism, Cambridge: Cambridge University Press, pp. 198-213.

DeYoung, R. K. (2009) Glittering Vices: A New Look at the Seven Deadly Sins and Their Remedies, Grand Rapids, MI: Brazos Press.

Maitreya, A., trans. (1995) The Dhammapada, Berkeley, CA: Paralax Press.

Donner, W. (2002) "Feminist Ethics and Anger: A Feminist Buddhism Reflection," APA Newsletter on Feminism and Philosophy 1(2): 67-70.

Doris, J. (2015) Talking to Our Selves, New York: Oxford University Press.

Frankfurt, H. (1998) “The Importance of What We Care About," in The Importance of What We Care About, New York: Cambridge University Press, pp. 80-94.

Frijda, N. (1987) The Emotions, Cambridge: Cambridge University Press.

Hazlitt, W. (2004/1826) The Pleasure of Hating, New York: Penguin Books.

Hill Jr., T. E. (1991) "Servility and Self-Respect," in Autonomy and Self-Respect, Cambridge: Cambridge University Press, pp. 4-18. 
Hume, D. (1978/1738) A Treatise of Human Nature, New York: Oxford University Press.

Hurka, T. (2001) Virtue, Vice, and Value, New York: Oxford University Press.

Jaggar, A. (1989) "Love and Knowledge: Emotion in Feminist Epistemology," Inquiry 32(2): 151-76.

Kenny, A. (1963) Action, Emotion and Will, London: Routledge \& Keegan Paul.

Kim, S. (2013) On Anger: Race, Cognition, Narrative, Austin, TX: University of Texas Press.

Long, A. A. (2002) Epictetus, Oxford: Clarendon Press.

Lorde, A. (1984) "Eye to Eye: Black Women, Hatred, and Anger," in Sister Outsider, Trumansburg, NY: Crossing Press, pp. 145-75.

Luther, M. (2004/1566) Table Talk, W. Hazlitt, trans., Orlando, FL: Bridge-Logos.

Marks, J. (1982) “A Theory of Emotion,” Philosophical Studies 42(2): 227-42.

McElroy, S. L., Soutullo, C. A., Beckman, D. A., Taylor Jr., P. and Keck Jr., P. E. (1998) "DSM-IV Intermittent Explosive Disorder: A Report of 27 Cases," Journal of Clinical Psychiatry 59(4): 203-10.

McRae, E. (2015) "Metabolizing Anger: A Tantric Buddhist Solution to the Problem of Moral Anger," Philosophy East and West 65(2): 466-80.

Mother Teresa (1996) The Joy in Loving: A Guide to Daily Living, J. Chaliha and E. Le Joly, eds., New Delhi: Viking.

Nussbaum, M C. (2016) Anger and Forgiveness: Resentment, Generosity, and Justice, New York: Oxford University Press.

(2015) "Transitional Anger" Journal of the American Philosophical Association 1(1): 41-56. (1994) The Therapy of Desire, Princeton: Princeton University Press.

Oakley, J. (1992) Morality and the Emotions, New York: Routledge.

Pereboom, D. (2009) "Free Will, Love, and Anger," Ideas y Valores: Revista Colombiana de Filosofía 141: 169-89.

Pettigrove, G. (2012) “Meekness and Moral Anger," Ethics 122(2): 341-70.

Plutarch (2008) In Consolation to His Wife, R. Waterfield, trans., New York: Penguin Books.

Prinz, J. (2004) Gut Reactions: A Perceptual Theory of Emotion, New York: Oxford University Press.

Roberts, R. C. (1988) "What an Emotion Is: A Sketch," The Philosophical Review 97(2): 183-209.

Rogers, F. (2003) The World According to Mister Rogers: Important Things to Remember, New York: Hyperion.

Śāntideva (Zhi-ba-lha) (2004) Byang chub sems dpa'i spyod pa la 'jug pa' (Bodhicaryāvatāra), Varanasi: Vajra Vidya Institute Library.

Scarantino, A. (2014) “The Motivational Theory of Emotions," in J. D'Arms and D. Jacobson, eds., Moral Psychology and Human Agency, New York: Oxford University Press, pp. $156-85$.

Seidman, J. (2016) "The Unity of Caring and the Rationality of Emotion," Philosophical Studies 173(10): 2785-801.

Seneca (2007) Dialogues and Essays, J. Davie, trans., New York: Oxford University Press.

Sher, G. (2005) In Praise of Blame, New York: Oxford University Press.

Slingerland, E. (2003) Effortless Action: Wu-wei as Conceptual Metaphor and Spiritual Ideal in Early China, New York: Oxford University Press.

Solomon, R. C. (2007) True to Our Feelings, New York: Oxford University Press.

Strawson, P. (1962) "Freedom and Resentment," in G. Watson, ed., Free Will, New York: Oxford University Press, pp. 72-93.

Tamir, M. (2009) "What Do People Want to Feel and Why? Pleasure and Utility in Emotion Regulation," Current Directions in Psychological Science 18(2): 101-5.

Tamir, M., Mitchell, C. and Gross, J. J. (2008) "Hedonic and Instrumental Motives in Anger Regulation," Psychological Science 19(4): 324-28.

Tavris, C. (1989) Anger: The Misunderstood Emotion, New York: Simon \& Schuster.

Taylor, G. (1975) "Justifying the Emotions," Mind 84(335): 390-402.

Tessman, L. (2005) Burdened Virtues: Virtue Ethics for Liberatory Struggles, New York: Oxford University Press. 
Velleman, J. D. (2008) “The Way of the Wanton,” in C. Mackenzie and K. Atkins, eds., Practical Identity and Narrative Agency, New York: Routledge, pp. 169-92.

Vernezze, P. (2008) “Moderation or the Middle Way: Two Approaches to Anger," Philosophy East and West 58(1): 2-16.

West, R. (2016) “Anger and the Virtues: A Critical Study in Virtue Individuation," Canadian Journal of Philosophy 46(6): 877-97.

Westlund, A. (2009) “Anger, Faith, and Forgiveness," The Monist 92(4): 507-36.

Wolf, S. (2011) "Blame, Italian Style” in R. J. Wallace, R. Kumar and S. Freeman, eds., Reason and Recognition: Essays on the Philosopby of T. M. Scanlon, New York: Oxford University Press, pp. 332-47.

(1982) "Moral Saints" The Journal of Philosophy 79(8): 419-39.

X, M. (1965) Malcolm X Speaks, New York: Grove Press. 